\title{
ANALISIS MOTIVASI KERJA GURU DI SMP NEGERI 21 SATU ATAP TELUK BINTAN KABUPATEN BINTAN
}

\author{
Satriadi \\ Sekolah Tinggi Ilmu Ekonomi (STIE) Pembangunan Tanjungpinang \\ satriadi@gmail.com \\ Muhamad Alny Kurnia Nugroho \\ Sekolah Tinggi Ilmu Ekonomi (STIE) Pembangunan Tanjungpinang \\ alnikurnia2310@gmail.com
}

\begin{abstract}
Abstrak: Tujuan dilakukannya penelitian ini adalah untuk mengetahui motivasi kerja intrinsic dan ekstrinsik yang mempengaruhi kinerja guru SMP Negeri 21 Satu Atap Teluk Bintan Kabupaten. Penelitian ini menggunakan metode deskrptif yang digunakan untuk mendeskriptifkan atau menggambarkan motivasi kerja guru SMP Negeri 21 Satu Atap Teluk Bintan Kabupaten Bintan. Objek penelitian adalah guru di SMP Negeri 21 Satu Atap Teluk Bintan Kabupaten Bintan. Tehnik penarikan sampel menggunakan tehnik purposive sample. Jenis data yang digunakan dalam penelitian ini adalah data primer yang didapat secara langsung dari wawancara dengan 10 informan termasuk informan kunci dan observasi. Penelitian ini juga menggunakan data sekunder yang didapat dari dokumen dan buku sebagai teori. Teknik pengolahan data yang digunakan adalah reduksi data, penyajian data, triangulasi sumber data dan penarikan kesimpulan. Dari hasil penelitian dan pembahasan yang telah di lakukan dapat disimpulkan bahwa motivasi kerja guru sudah cukup baik namun masih perlu di tingkatkan. Motivasi intrinsic yang mempengaruhi motivasi kerja terdiri dari keberhasilan guru, penghargaan, pekerjaan itu sendiri, tanggung jawab dan pengembangan. Sedangkan motivasi ekstrinsik yang mempengaruhi motivasi kerja guru SMP Negeri 21 Satu Atap Teluk Bintan Kabupaten Bintan adalah. Kebijakan administrasi, hubungan antar pribadi, kondisi kerja dan gaji. Dari hasil penelitian dan pembahasan yang telah dilakukan disimpulkan bahwa motivasi kerja guru sudah cukup baik namun masih perlu di tingkatkan lagi. Agar motivasi kerja guru SMP Negeri 21 Satu Atap Teluk Bintan Kabupaten Bintan semakin baik lagi.
\end{abstract}

Kata Kunci: motivasi, kerja guru, Bintan, faktor intrinsik, faktor ekstrinsik.

Abstract: The puspose of this research is to know about the intrinsic and ekstrinsic work motivation that affected to the teacher perfotmance of SMP Negeri 21 Satu Atap Teluk Bintan Kabupaten Bintan. The study uses a descriptive method to description or to describe the motivation for the work of thechers SMP Negeri 21 Satu Atap Teluk Bintan Kabupaten Bintan. The object of the research is the teachers of SMP Negeri 21 Satu Atap Teluk Bintan Kabubupaten Bintan. sampel withdrawal techniques using sampel purposive sampling. The type of data used in this study is primary data that can come directly also used secondary data obtained from the files in the book as atheory. The gummed data processing techniqes are data reduction, data presentation, triangulasi of data sources and deduction withdrawal. People to be a sample from SMP Negeri 21 Satu Atap Teluk Bintan Kabupaten Bintan. The results of research and discussions that has been done, and the concluded that the teacher work motivation is good enough but still need to be increased. Intrinsic motivation that affected to the work motivation consists of the success of the teacher, the achievements, the work itself, responsibility and development. While the extrinsic motivation that affeced to work motivation is the policy and administration, interpersonal relationships, working condition and salary of theacher's at SMP Negeri 21 Satu Atap Teluk Bintan. The result of the research and discussion has been done and the concluded that the teachers work motivation 
good enough but still need to be increased or need to have improvement so that SMP Negeri 21 Satu Atap Teluk Bintan Kabupaten Bintan will get better in the future.

Keywords: motivation, teacher work, Bintan, intrinsic factors, extrinsic factors.

\section{PENDAHULUAN}

Di era globalisasi seperti saat ini, banyak dibutuhkan sumber daya manusia yang ahli dan kompeten dalam segala bidang. Oleh sebab itu, banyak sekali tempat pendidikan dan pembibitan calon sumber daya tersebut berkembang di masyarakat, baik yang di pemerintah maupun swasta.

Sumberdaya manusia merupakan hal penting dalam organisasi yang sangat vital, oleh karena itu peran dan fungsinya tidak dapat digantikan dengan sumber daya lainnya. Menurut (Hasibuan, 2014) sumber daya manusia adalah kemampuan dari daya fikir dan daya fisik yang dimiliki individu. Sumber daya manusia merupakan salah satu sumber yang paling menentukan sukses tidaknya sebuah perusahaan atau organisasi. Berapapun modern teknologi yang digunakan, dan seberapa banyak dana yang disiapkan, namun jika tidak ada sumber daya yang professional semuanya menjadi tidak bermakna. Sumber daya manusia yang baik dan unggul sangat diutamakan dalam mencapai terwujudnya bangsa dan negara yang maju dan berkualitas. Dalam hal ini suatu bangsa tidak dapat berkembangan maju dengan baik tanpa adanya pendukung termasuk dalam bidang pendidikan.

Proses pendidikan tidak akan berjalan dengan baik tanpa adanya sumber daya manusia yaitu guru. Kepala sekolah sebagai top manajer atau pemimpin pendidikan, diharapkan dapat melaksanakan tugasnya dengan baik untuk dapat mempengaruhi bawahannya, khususnya guru sebagai upaya untuk meningkatkan mutu pendidik. Salah satu upaya yang bisa dilakukan adalah melalui pemberian motivasi pada rekan kerja atau bawahannya. Kepala sekolah tidak hanya diberikan perintah untuk mengetahui bagaimana caranya untuk menumbuhkan motivasi dari luar (ekstrinsik) pada guru, namun juga wajib dapat mengajak guru untuk bisa menumbuhkan motivasi dalam diri sendiri (Intrinsik). Pemberian motivasi tersebut, bertujuan untuk mengembangkan semangat kerja dalam diri guru, demi tercapai tujuan sekolah untuk dapat mencapai hasil pembelajaran yang sangat maksimal.

Menurut Undang-Undang Republik Indonesia Nomor 14 Tahun 2005 Pasal 1 Tentang Guru Dan Dosen, “ guru adalah pendidik professional dengan tugas utama mendidik, mengajar, membimbing, mengarahkan, melatih, menilai, dan mengevaluasi peserta didik pada pendidikan anak usia dini, jalur pendidikan formal, pendidikan dasar, dan pendidikan menengah". Oleh karena itu guru merupakan unsur pokok dalam menunjang keberhasilan 
suatu organisasi, karena guru adalah sumber tenaga dari seluruh aktifitas yang dilakukan organisasi.

Kinerja guru merupakan kemampuan dan keberhasilan guru dalam melakukan tugastugas dalam pembelajaran. Menurut Sedarmayanti (2016) kinerja guru merupakan kemampuan dan keberhasilan guru dalam melaksanakan tugas- tugas pembelajaran. Kinerja guru dipengaruhi oleh beberapa faktor. Faktor bisa mempengaruhi kinerja yaitu, motivasi kerja, disiplin kerja, dan etika kerja. Berdasarkan faktor-faktor yang mempengaruhi aspek kinerja guru yang telah dijelaskan di atas, salah satu yang mempengaruhi kinerja guru adalah faktor motivasi kerja yang dimiliki oleh masingmasing individu. Hal yang penting dan ikut berperan dalam menentukan berhasil tidaknya proses pembelajaran yang dilakukan oleh guru yaitu motivasi kerja yang dimiliki.

Menurut Hartatik (2014) motivasi kerja merupakan suatu perangsang keinginan dan daya penggerak kemauan yang menciptakan kegairahan seseorang untuk mencapai suatu tujuan yang di kehendaki. Motivasi kerja tinggi yang di berikan karyawan akan meningkatkan produktivitas perusahaan, sehingga memudahkan pencapaian tujuan perusahaan yang telah di tetapkan. Winardi (2011) berpendapat, individu yang belum termotivasi hanya akan memberikan upaya minimum dalam pekerjaannya. Hal ini menjelaskan bahwa motivasi merupakan komponen yang penting di dalam kinerja kerja individu.

Faktor yang mempengaruhi meninggi dan menurunnya motivasi kerja seseorang adalah minat atau perhatian terhadap pekerjaan, upah/gaji, status sosial dari pekerjaan, pekerjaan yang mengandung pengabdian dan faktor suasana kerja serta hubungan kemanusiaan yang baik. Menurut Marni, (2013) dalam penelitian yang telah dilakukan, peneliti menggaris bawahi bahwa motivasi merupakan suatu kekuatan yang mendorong seseorang dalam melakukan suatu kegiatan. Motivasi dapat mempengaruhi prestasi seorang guru dalam melakukan pekerjaannya.

Berdasarkan penelitian yang dilakukan oleh Masuku (2013) dijelaskan bahwa tenaga kerja ahli yang kurang dapat mempengaruhi motivasi kerja dimana dalam penelitiannya terdapat motivasi kerja yang rendah dikarnakan kekurangan SDM yang ahli dalam pekerjaannya. Ini dapat di menimbulkan beban kerja di setiap pegawai untuk bekerja dengan ekstra selain itu dengan beban kerja yang menambah namun gaji, fasilitas, kondisi kerja yang kurang juga dapat memperburuk motivasi kerja tersebut.

Sekolah Menengah Pertama Negeri 21 Satu Atap Teluk Bintan yang Beralamatkan di jalan Bintan Enau RT. 9 RW. 5, RT/RW 9/5, Ds./Kel Bintan Buyu, Kec. Teluk Bintan, Kab. Bintan. Sekolah Menengah Pertama Negeri 21 Satu Atap Teluk Bintan membekali siswanya untuk menjadikan 
karakter siswa-siswi yang baik dan mempunyai wawasan dan ilmu dalam dunia pendidikan yang baik dan berbudi luhur baik pula. Maka dengan demikian untuk mewujudkan hal diatas maka pihak kepala Sekolah Menengah Pertama Negeri 21 Satu Atap Teluk Bintan menginginkan guru-guru yang mempunyai kinerja yang baik, pendidikan, keterampilan, skill dan wawasan yang luas, kedisiplinan serta semangat kerja yang tinggi, agar bisa menjadi teladan dan contoh bagi siswanya. Berikut adalah data guru di Sekolah Menengah Pertama Negeri 21 Satu Atap Teluk Bintan:

Table 1.1

Jumlah Pendidik Dan Tenaga Kependidikan Di SMP Negeri 21 Satu Atap Teluk Bintan Kabupaten Bintan

\begin{tabular}{|c|c|c|c|c|c|c|c|c|c|}
\hline \multirow{2}{*}{ No } & \multirow{2}{*}{$\begin{array}{c}\text { Jenis } \\
\text { kegiatan }\end{array}$} & \multicolumn{2}{c|}{$\begin{array}{c}\text { Jenjang } \\
\text { pendidikan }\end{array}$} & \multicolumn{2}{c|}{$\begin{array}{c}\text { Sertifikasi } \\
\text { guru }\end{array}$} & \multicolumn{2}{c|}{$\begin{array}{c}\text { Masa } \\
\text { kerja/tahun }\end{array}$} & \multicolumn{2}{c|}{ Status kerja } \\
\cline { 3 - 10 } & S2 & S1 & Ya & Tidak & $>5$ & $<5$ & PNS & Honorer \\
\hline 1 & Pendidik & 1 & 8 & 3 & 6 & 3 & 6 & 8 & 1 \\
\hline 2 & $\begin{array}{c}\text { Tenaga } \\
\text { Pendidik }\end{array}$ & - & 1 & - & 1 & 1 & - & 1 & - \\
\hline \multicolumn{6}{|c|}{ Total } & \multicolumn{8}{|c|}{10} \\
\hline
\end{tabular}

Sumber: Data yang diperoleh dari SMP N 21 Satu Atap Teluk Bintan untuk penelitian (2019)

Bisa dilihat bahwa terdapat 3 guru yang baru mendapatkan sertifikasi guru hal ini dapat di simpulkan bahwa di sekolah SMP Negeri 21 satu atap teluk Bintan masih terdapat banyak guru yang belum bersertifikat yang mana menandakan bahwa guru tersebut belum memiliki bukti formal sebagai pengakuan yang diberikan kepada guru sebagai tenaga profesional, yang mana terdapat pada peraturan pemerintah nomor 19 pasal 1 tahun 2017 tentang guru dimana dikatakan bahwa sertifikasi pendidik adalah bukti formal sebagai pengakuan yang diberikan kepada guru sebagai tenaga profesional.

Selanjutnya dapat dilihat bahwa terdapat guru yang mengajarkan pelajaran yang tidak sesuai dengan pendidikannya sedangkan tertulis jelas bahwa pada peraturan pemerintah nomor 19 pasal 15 tahun 2017 tentang guru di jelaskan bahwa aktif mengajar sebagai guru mata pelajaran dan/guru kelas pada satuan pendidikan yang sesuai dengan peruntukan sertifikasi pendidik yang dimiliki. Hal ini dapat menimbulkan beban kerja pada guru/pengajar tersebut sehingga perlunya motivasi yang diberikan.

Dari hasil observasi dan wawancara kepada guru di SMP Negeri 21 tersebut terdapat juga beberapa fenomena yang mana diantaranya. sering juga di jumpai guru hanya memberikan tugas kepada peserta didik dan guru tersebut kembali keruangannya untuk beristirahat sehingga kurang efektif terhadap pembelajaran. Serta terdapat pula guru yang datang tidak tepat waktu sehingga membuat kelas yang di ajarnya kosong sehingga tidak dapat secara optimal dalam mengajar sehingga dapat dilihat bahwa masih kurang termotivasi dalam mengajar.

Berdasarkan latar belakang dan fenomena yang terjadi yang telah dijelaskan diatas maka penelitian ini difokuskan untuk mengetahui “Analisis Motivasi Kerja Guru 


\section{Di SMP Negeri 21 Satu Atap Teluk Bintan".}

\section{Rumusan Masalah}

Berdasarkan latar belakang masalah yang telah diuraikan sebelumnya, maka untuk mempermudah dalam pembahasan maka penulis mengemukakan rumusan masalah sebagai berikut:

"Bagaimana Motivasi Kerja Pada Guru di SMP Negeri 21 Satu Atap Teluk Bintan?"

\section{Tujuan Penelitian}

Penulis melakukan ini tentunya memliki maksud dan tujuan tertentu, adapun maksud dan tujuan penelitian ini adalah:

"Untuk mengetahui bagaimana Motivasi Kerja Pada Guru di SMP Negeri 21 Satu Atap Teluk Bintan.”

\section{Kegunaan Penelitian}

\section{Kegunaan Teoritis}

1. Hasil penelitian ini untuk menambah ilmu pengetahuan dalam pengembangan penelitian ini memperkuat teori motivasi kerja pada guru di SMP Negeri 21 Satu Atap Teluk Bintan.

2. Untuk menambah wawasan pengetahuan dalam bidang penelitian, khususnya yang berkaitan dengan motivasi kerja guru di SMP Negeri 21 Satu Atap Teluk Bintan.

\section{Kegunaan Praktis}

1. Bagi sekolah penelitian ini bermanfaat untuk memberikan gambaran mengenai motivasi kerja guru di SMP Negeri 21
Satu Atap Teluk Bintan. Dan diharapkan dapat dijadikan sebagai peningkatan Motivasi kerja.

2. Bagi peneliti sebagai tambahan pengetahuan dan wawasan bagi peneliti untuk menerapkan ilmu yang didapatkan selama mengikuti perkuliahan dan mengembangkan kemampuan peneliti dalam melakukan penelitian.

\section{METODE PENELITIAN}

\section{Kerangka Pemikiran}

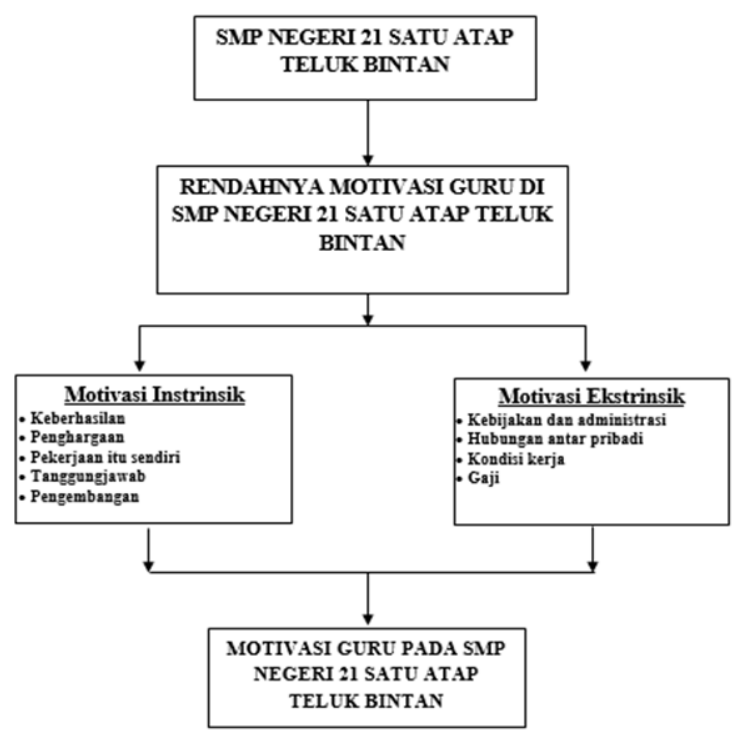

Sumber : Penelitian (2019)

\section{Jenis Penelitian}

Dalam penelitian ini, jenis penelitian yang digunakan adalah penelitian deskriptif kualitatif. Sumber data yang digunakan dalam penelitian ini adalah data primer dan data sekunder. Sumber data dalam penelitian ini adalah data yang diperoleh dari lapangan dengan cara mengamati atau mewawancarai langsung responden tentang motivasi kerja.

\section{Metode Pengumpulan Data}


Dalam pengumpulan data yang digunakan oleh penulis adalah observasi, dokumentasi dan wawancara.

\section{Populasi dan Sampel}

Adapun populasi dalam penelitian ini adalah kepala sekolah dan guru di SMP NEGERI 21 SATU ATAP TELUK BINTAN yang dimana berjumlah 10 orang.

Dalam penelitian ini menggunakan purposive sampling. Purposive sampling adalah teknik pengambilan sampel dengan menentukan kriteria-keriteria tertentu. Jadi jumlah sampel yang di ambil dalam penelitian ini berjumlah 10 orang, terdiri dari 1 informan kunci dan 9 sebagai informan pendukung.

\section{Teknik Pengolahan Data}

1. Reduksi Data

Dimana setelah peneliti memperoleh data, harus lebih dulu dikaji kelayakannya dengan memilih data mana yang benarbenar dibutuhkan dalam penelitian ini.

\section{Penyajian Data}

Dalam peneliti ini akan menyajikan data dalam bentuk teks, untuk memperjelas hasil penelitian maka dapat dibantu dengan mencantumkan tabel atau gambar.

\section{Triangulasi}

Didalam penelitian ini menggunakan teknik triangulasi sumber, dimana teknik triangulasi dengan sumber berarti kita membandingkan dan mengecek balik derajat kepercayaan suatu informasi yang diperoleh melalui waktu dan alat yang berbeda dalam penelitian kualitatif.

4. Verifikasi (Menarik Kesimpulan)

Kesimpulan dalam penelitian kualitatif merupakan temuan baru yang sebelumnya belum pernah ada temuan, dapat berupa deskripsi atau gambaran suatu objek yang dapat berupa hubungan kausal atau interaktif hipotesis atau teori.

\section{HASIL DAN PEMBAHASAN}

\section{Analisis Data}

\section{Reduksi Data}

Untuk mengetahui motivasi kerja guru smp negeri 21 satu atap Teluk Bintan kabupaten Bintan adalah data dari hasil wawancara dengan guru dan staf.

1. Motivasi Kerja Instrinsik Guru Pada SMP N 21 Satu Atap

a. Keberhasilan

Dari wawancara dengan informan pada tanggal 11 Desember 2020 menyatakan sebagai berikut: "pencapaian yang saya raih selama menjabat di sekolah Alhamdulillah sudah banyak. salah satunya sebagai oprator terbaik yang di berikan oleh dinas pendidikan yaitu oprator bagian administrasi sekolah" (IW).

Berdasarkan pernyataan informan diatas, bahwasanya keberhasilan dapat di lihat dari hasil pencapaian yang ia peroleh di sekolah.

Hal yang serupa juga di katakana oleh informan sebagai berikut: "menurut 
saya pencapaian yang saya raih dalam bekerja dan menjadi guru ialah dimana saya berhasil membawa murid saya untuk perlombaan OSN jenis sains dan mendapat pringkat 3 di tingkat kab/kota. Namun jika di lihat dari karir saya di smp tersebut begitu saja hanya sebagai guru pengajar di sekolah tersebut" (SN).

Berdasarkan pernyataan informan diatas dapat disimpulkan bahwasanya keberhasilan seorang guru dilihat dari beberapa pencapaian yang di raih untuk keberhasilannya meskipun jika dilihat dari karir guru tersebut dapat dilihat bahwa karirnya berhenti hanya sebagai guru pengajar.

Hal ini sama seperti yang di sampaikan oleh informan sebagai berikut: "pencapaian yang saya dapatkan tidak ada dimana saya hanya sebagai guru pengajar yang di percaya untuk mengajar sesuai keahlian yang dimiliki dan yang saya rasakan dengan karir saya selama guru di sekolah tersebut, yang saya rasakan hanya sebatas menjadi guru saja" (SI).

Berdasarkan hasil wawancara tersebut, menunjukkan bahwa terdapat para guru yang merasakan bahwasanya tingkat keberhasilan yang mereka rasakan masih kurang dimana terdapat beberapa guru yang merasakan keberhasilan namun terdapat juga guru yang merasakan ketidak atau belum untuk mencapai keberhasilan yang di inginkan.

b. Penghargaan

Berdasarkan hasil wawancara terhadap penghargaan yang didapatkan dengan informan pada tanggal 11 Desember 2020 dari apa yang diberikan pada sekolah terhadap pegawai yang berprestasi, disiplin atau mencapai target yang diberikan sebagai berikut: "kalo masalah target sekolah kami mengacu pada visi kita namun jika mendapatkan pengharggan biasannya ucapan selamat dan trimakasih dari atasan" (DW).

Berdasarkan hasil wawancara informan tersebut, menunjukkan bahwasannya mengenai penghargaan yang diperoleh oleh para guru sudah cukup baik dimana atasan selalu melihat dan memantau hasil pekerjaan bawahannya dan memberikan apresiasi terhadap bawahannya yang berhasil dengan apa yang di tugaskan dan mampu menyelesaikannya.

Hal ini juga yang disampaikan informan sebagai berikut: "mendapatkan ucapan dan biasannya di berikan seperti piagam sebagai guru terbaik atau sebagai penghargaan dan penghargaaan lainnya. Dan atasan selalu menilai biasannya dengan ucapan atau perkataan bahwa keperjaan saya sudah baik bahkan jika masih kuruang atasan masih memberi 
tahu dengan perkataan dengan baik" (IS).

Berdasarkan dari hasil wawancara informan tersebut dapat disimpulkan bahwasannya terhadap masalah penghargaan sudah sangat baik dimana setiap guru selalu diperhatikan oleh atasannya dimana telah sesuai dengan hasil observasi yang dilihat oleh peneliti.

Begitu juga dengan hasil wawancara yang disampaikan oleh informan pada tanggal 15 Desember 2020 sebagai berikut: "yang saya lihat biasannya di beri seperti pengharggaan seperti piagam dan ucapan yang memberikan semangat dan atasan menilai hasil kerjaan kita agar dapat memberi pemacu terhadap guru agar semangat" (RON).

Berdasarkan hasil wawancara yang didapatkan oleh informan dan para guru lainnya dapat diambil kesimpulan bahwasannya hal dimana atasan selalu memberikan apresiasi terhadap apa yang dilakukan oleh bawahannya agar termotivasi dalam melakukan atau mengerjakan pekerjaan atau tugas yang telah ditugas atau di emban oleh setiap guru di sekolah tersebut.

c. Pekerjaan Itu Sendiri

Berdasarkan dari hasil wawancara mengenai pekerjaaan itu sendiri oleh informan pada tanggal 11 Desember 2020 sebagai berikut: “dimana dalam pekerjaan tersebut terdapat kebosannan di saat tugas yang di berikan oleh atasan namun selalu bersukur telah di berikan kepercayaan oleh atasan atau kepala sekolah. Dan sangat bangga dikarnakan saya dipercayai untuk mengajar di sekolah tersebut dan sangat memahami pekerjaan itu sendiri dikarnakan sebagai guru ialah sebagai pembimbing dan pengajar kepada murid-muridny dan sudah sesuai dengan keahlian yang saya miliki namun dengan adanya tugas tambahan membuat sedikit tidak sesuai dengan keahlian yang saya miliki” (SN).

Berdasarkan dari hasil wawancara pada informan dapat dilihat bahwasnya terdapat kebosanan dalam pekerjaan itu sendiri dimana terdapat tugas tambahan yang diberikan namun para guru merasa bangga dengan pekerjaan itu sendiri dikarnakan iya sudah dipercayai sebagai guru untuk mengajar para murid-muridnya di sekolah tersebut.

Hal ini juga sama apa yang di sampaikan oleh informan sebagai berikut. "jika dikatakan bosan tentu bosan yang mana selama 12 tahun yang saya kerjakan seperti it uterus sehingga menimbulkan kejenuhan bagi saya. Namun saya bangga bekerja di sini karena saya masih do percaya dari kawan kawan dan guru untuk 
mengerjakan tugas saya di sekolah ini.dan sangat memahami dengan adanya saya di sekolah ini, sekolah mempercayai tugas yang saya terima untuk menjalankan proses dalam berjalannya sekolah tersebut di bidang administrasi dan lainnya. Dan jika di Tanya tentang sesuai atau tidaknya pekerjaan tersebut menurut saya sudah sesuai di karnakan dari kecil saya bercita-cita untuk bekerja dikantoran dan sudah terwujud namun masih ingin menjadi pns" (IW).

Berdasarkan hasil wawancara yang di dapatkan oleh informan dapat di artikan bahwasnnya terdapat kebosannan dalam bekerja di sekolah tersebut sehingga menurunkan motivasi dalam bekerja di mana di lihat terdapat kejenuhan dengan tugas yang dia terima dari tahun ke tahun.

Hal ini juga di sampaikan oleh informan sebagai berikut: "terkadang sedikit membosankan dengan beban kerja saya dimana saya di percaya untuk memberikan pelajaran dua mata pelajaran tik da ipa namun saya bangga dikarnakan saya sudah di percaya di sekolah tersebut oleh rekan dan atasan saya yang mana di berikan pekerjaan kepada saya dan saya memahami pekerjaan tersebut dimana dengan saya bekerja tersebut untuk memberikan impek terhadap pengetahuan kepada siswa yang saya ajarkan dan jika di Tanya tentang pekerjaan tersebut sudah sesuai atau belum kalo dibilang sudah namun di karnakan saya di berikan pekerjaan untuk merangkap sebagai guru tik yang mana saya bukan ahlinya membuat saya kadang sedikit kewalahan dalam tugas yang saya terima" (IS).

Berdasarkan hasil dari wawancara para guru terdapat beberapa guru dalam pekerjaan tersebut menimbulkan kebosanan dimana terdapat beban kerja yang bertambah di tambah lagi beban yang di terima tidak sesuai dengan keahlian yang mereka miliki sehingga meberikan beban kerja bagi guru-guru yang mendapatkan tugas tambahan untuk mengajar. Dengan beban kerja yang buruk membuat kinerja menurun pula sehingga jika kinerja menurun membuat menurun pula motivasi guru dalam mengajar dan bekerja di sekolah tersebut.

d. Tanggung Jawab

Berdasarkan hasil wawancara dengan informan pada tanggal 18 Desember 2020 sebagai berikut: "tanggung jawab dimana saya di berikan tuugas sebagai guru yang mengajar dua pelajaran dan di bagian perpustakaan sehingga mebutuhkan banyak waktu yang di habiskan. Dan jika di Tanya tentang apakah tangguang jawab telah sesuai dengan keahlian menurut saya tidak 
sesuai namun demi kelanjutan persekolahan dengan kekurangan guru tersebut membuat saya harus mengambil tugas itu" (IRA).

Berdasarkan dari hasil wawancara diatas menunjukkan bahwasannya terdapat tanggung jawab yang begitu banyak sehingga membuat banyak mengeluarkan waktu yang banyak dalam mengerjakan tanggung jawab yang telah diberikan sehingga membuat terporsirnya tenaga dalam mengajar selain itu terdapat tanggung jawab yang mana tidak sesuai dengan keahlian atau kemampuan yang dimiliki oleh guru tersebut namun demu berjalannya proses pembelajaran sehingga guru harus mengemban tugas tersebut.

Hal tersebut sama seperti apa yang didapat dari hasil ovservasi di mana terdapat beberapa guru yang harus mengajar ganda dan tidak sesuai dengan keahlian dan bidang yang ia kuasai selama dibanggku perkuliahan sehingga membuat tekanan dan beban kerja yang tinggi.

Sama seperti dengan hasil wawancara pada informan pada tanggal 15 Desember 2020 sebagai berikut: "tanggung jawab dimana saya harus mendidik murid saya berpengetahuan dan berahlak baik namun dengan tanggung jawab yang saya dapatkan menurut saya kurang sesuai dimana saya berkelulusan fisika harus di tambah dengan memberikan pelajaran pjok demi membantu kekurangan guru tersebut" (RON).

Berdasarkan hasil wawancara diatas dapat diketahui bahwa dengan tanggung jawab yang tidak sesuai dengan keahlian yang dimiliki dapat membuat tingkat keberhasilan dalam memberikan pengetahuan sangat kurang dan akan membuat guru semakin setres dalam mengajar tingkat stress yang meningkat akan menurunkan motivasi dalam mengajar sehingga membuat para guru tidak termotivasi dalam mengajar muridmuridnya.

Namun ada beberapa guru yang merasa telah sesuai dengan apa yang dia inginkan di karnakan tanggungnjawab yang dia terima tidak seperti guru lainnya seperti hasil wawancara pada informan pada tanggal 11 Desember sebagai berikut: "tanggung jawab sebagai guru yaitu mengajar siswanya untuk menambah pengetahuan siswanya dan mendidik berahlak yang baik dan menurut saya tanggung jawab yang saya terima sudah sesuai dengan apa yang saya kuasai dan saya tempuh pembelajarannya" (DW).

Berdasarkan dari hasil diatas dapat ditarik benang merah dimana terdapat juga beberapa guru yang mendapat 
tugas dan tanggung jawab sesuai porsinya namun ada juga yang dimana guru harus bertanggung jawab dengan tugas atau beban yang sebenarnya tidak ia lakukan namun demi kebutuhan dan sebagai penutup kekurangan yang ada di sekolah tersebut membuat para guru harus mengerjakan tugas tersebut.

e. Pengembangan

Berdasarkan dari hasil wawancara yang di peroleh dari informan pada tanggal 11 Desember 2020 sebagai berikut dalam masalah perkembangan: "perkembangan saya selama mengajar yaitu saya telah tersertifikasi guru yang mana di sekolah saya mengajar masih sangat minim guru yang tersertifikasi.dan pihak sekolah memberikan izin dalam mengembangkan ilmu dan menembuh pendidikkan asalkan tidak mengganggu aktifitas mengajar dan para guru mendapatkaan pelatihanpelatihan agar dapat mengembangkan dan menambah pengetahuan dalam ngajar mengajar" (SN).

Berdasarkan hasil wawancara informan dapat dilihat dari pengembangan bahwasannya para guru sudah berkembang sangat baik dengan beberapa pencapaian dan berkembangan yang dimiliki sehinngga dapat dikatakan baik dan menambah dalam termotivasinya para guru dikarnakan selalau diberikan tambahan ilmu dan diberikan kekuasaan untuk mengembangkan kemampuan dan ilmu pengetahuan disetiap guru.

Hal serupa juga dikatakan pada hasil wawancara pada informan pada tanggal 15 Desember 2020 sebagai berikut: "perkembangan yang saya rasakan ya itu saya dapat mengetahui bagaimana proses dalam mengajar yang tidak saya jumpai di banggu perkuliahan dan pihak sekolah mengijinkan untuk mengembangkan pengetahuan asal tidak mempengaruhi tugasnya dan para guru juga selalu mendapatkan pelatihan-pelatihan dari dinas LPMP dan dinas kementrian dalam hal ngajar-menajar" (SI).

Berdasarkan dari hasil diatas dapat dilihat bahwasannya sama seperti hasil observasi penulis dimana terdapat guru yang mengikuti pelatihan dari dinas untuk menambah pengetahuan mereka dalam mengajar murid dengan baik dan benar sesuai dengan kurikulum dan metode yang dianjurkan oleh kementrian pendidikan. Hal tersebut dapat disimpulkan bahwasannya dalam masalah pengembangan pada guru tersebut sudah cukup baik dimana pihak sekolah dan dinas yang terkait memperhatikan para guru agar selalu berkembang dalam bidang pengetahuan dan tugasnya. 


\section{Motivasi Kerja Ekstrinsik Guru Pada} SMP N 21 Satu Atap

a. Kebijakan dan Administrasi

Berdasarkan dari wawancara dari kebijakan dan administrasi pada informan pada tanggal 11 Desember 2020 sebagai berikut: "menurut saya atasan atau kepala sekolah tempat saya bekerja sangat baik dan memberikan kepercayaan guru-guru atas tugasnya sehingga meberikan kebebasan kepada guru-guru" (SN).

Berdasarkan hasil wawancara dapat diatas dimana dapat diketahui bahwasannya atasannya memberikan kebijakan kepada tugas guru untuk mengaturnya sendiri sehingga memberikan kebebasan terhadap tugas yang diberikan.

Sama halnya dengan hasil wawancara pada infprman sebagai berikut: "sangat baik di karnakan selalu mempercayai kepada bawahannya" (DW).

Berdasarkan hasil wawancara tersebut dapat diketahui bahwasannya para guru sudah diberikan kepercayaan untuk tugasnya.

Namun ada beberapa hasil yang lain pada hasil wawancara pada informan sebagai berikut: "cukup baik dokarnakan biasanya atasan memberikan pengarahan dengan cara berbicara kepada bawahannya dengan jelas meskipun terkadang harus menugaskan bawahannya untuk melengkapi kekurangan yang berada di sekolah tersebut salah satunya mengajar tambahan" (IS).

Berdasarkan hasil diatas penulis menemukan hasil yang sama di mana terdapat kebijakan yang membuat guru merasa dibebani oleh tugasnya seperti pada hasil wawancara pada informan pada tanggal 15 Desember 2020 sebagai berikut: "menuruut saya sedikit memberatkan kepada saya di karnakan itu membuat saya harus mengerjakan dua tugas bahkan tiga tugas yang kadang membuat saya stress dan jenuh" (RON).

Berdasarkan dari hasil wawancara diatas dapat diketahui bahwasannya kebijakan yang dimana harus menambahkan tugas bawahannya membuat beberapa guru merasa keberatan sehingga membuat berkurangnya dalam mengajar sehingga menurunnya motivasi dalam mengajar di sekolahan tersebut.

Namun keputusan atau kebijakan yang diberikan atasaan memang seharusnnya dilakukan dikarnakan untuk memenuhi kekurangan yang terjadi seperti pada hasil wawancara yang diperoleh pada informan pada tanggal 18 Desember 2020 sebagai berikut: "keputusan yang memang harus di ambil sehingga memang seharusnya hal seperti dan kondisi 
yang memang di ambil meskipun ada memberatkan salah satu pihak" (IRA).

Berdasarkan dasil wawancara diatas dapat disimpulkan bahwasnnya masih terdapat kebijakan yang memberatkan para guru dengan keputusan yang diambil oleh atasan namun hal tersebut yang dapat diambil untuk dapat mengatasi kekurangan dan jalan keluar yang baik.

b. Hubungan antar pribadi

Berdasarkan hasil wawancara pada hubungan antar pribadi dapat dilihat pada hasil wawancara pada informan pada tanggal 11 Desember 2020 sebagai berikut: "baik dan saling bekerja sama dalam pekerjaan dan saling berdiskusi sih sehingga memecahkan masalah dengan bersama-sama" (IW).

Berdasarkan hasil pada wawancara informan dapat dilihat bahwasannya dalam hungungan antar pribadi sudah sangat baik dimana para guru selalu bekerja sama dan berbicara untuk melakukan suatu keputusan.

Sama halnya dengan hasil wawancara pada informan pada tanggal 18 Desember 2020 sebagai berikut: "baik dan terkadang saya mencari dahulu namun jika tidak mendapatkan baru saya menanyakan kepada rekan saya" (RS).

Berdasarkan hasil wawancara pada informan sama hal nya dengan hasil wawancara pada informan sebagai berikut: "saya rasa cukup baik dengan rekan-rekan di tempat saya kerja dan sering sekali dan rekan kerja saya sangat baik dalam menanggapi kesulitan saya" (IRA).

Berdasarkan hasil wawancara di atas dapat di simpulkan dalam hubungan antar pribadi sangat baik dimana para guru saling berkerjasama dan saling membantu dalam permasalahan yang di hadapi hal tersebut sesuai dengan hasil observasi yang penulis lihat di lapangan di mana para guru saling berkomunikasi bersama dan selalu menanyakan apa saja hal yang mereka tidak ketahui.

c. Kondisi kerja

Berdasarkan hasil wawancara pada informan pada tanggal 11 Desember 2020 sebagai berikut: "sejauh ini sudah nyaman dengan keadaan sekolah meskipun jarak yang di tempuh sedikit jauh dari rumah kesekolah dan Alhamdulillah sudah terpenuhi seperti leptop danperalatan yang di butuhkan untuk mengerjakan pekerjaan sekolah meskipun dahulunya masih belum ada" (IW).

Berdasarkan hasil wawancara di atas dapat dilihat terhadap masalah kondisi kerja dimana sudah baik dengan fasilitas yang diberikan dapat dilihat bahwasannya sudah terprnuhi dalam bekerja. Fasilitas yang memadai dapat 
mempermudah dan melancarkan suatu pekerjaan dengan baik sehingga dengan pekerjaan yang baik membuat para guru termotivasi dan semangat dalam mengajar di karnakan fasilitas yang diterima sudah sesuai dan baik untuk mengerjakan tugas dan tanggung jawab yang diberikan oleh atasan.

Sama halnya dengan hasil wawancara pada informan sebagai berikut: "menurut saya sudah cukup baik dan sudah cukup dalam kelengkapan yang saya butuhkan" (DW).

Berdasarkan hasil wawancara diatas dan beberapa guru terhadap masalah kondisi kerja yang dimana sudah cukup baik dengan fasilitas yang diterimanya sehingga dapat termotivasi dalam mengerjakan pekerjaannya dengan baik namun terdapat beberapa guru yang merasa kondisi kerja mereka belum sesuai dengan yang dinginkannya.

Dimana terdapat pada hasil wawancara pada informan yang mana sebagai berikut: "menurut saya pekerjaan saya sudah cukup baik dan sudah nyaman namun jika bilang fasilitas menurut saya masih belum dikarnakan sebagai guru tik di sekolah belum mempunyai ruang computer dan computer untuk melakukan pembelajaran dimana dimana hanya dengan buku saja dan saya sangat mendorong adanya motivasi dikarnakan dengan fasilitas yang terbatas sangat membuat saya dan rekan lainnya kesulitan dalam proses pembelajaran.” (IS).

Berdasarkan hasil wawancara diatas dapat disimpulkan bahwasannya ada beberapa guru yang merasa kurang dalam kondisi kerjanya salah satunya yaitu fasilitas yang diterimannya sehingga terdapat beberapa guru yang merasa kesulitan dalam mengajar sehingga membuat pekerjaan dan penyampaian dalam mengajar sedikit sulit dan kurang baik dalam pemberian ilmu dan pengetahuannya.

d. Gaji

Pada umumnya seseorang bekerja untuk memperoleh gaji yang mana untuk memenuhi kebutuhan pribadinya sehingga dengan gaji yang tingi dapat membuat semangat dan termotivasi dalam bekerja.

Berdasarkan hasil wawancara pada informan terhadap persoalan gaji tersebut: "jika dibilang ingin naik gaji tentu semua orang ingin naik gaji dikarnakan kebutuhan saat ini semakin lama semakin meningkat dan jika di lihat apakah sudah sesuai dengan pekerjaan saya menurut saya belum sih dengan beban kerja yang banyak dan berat sehingga saya harus meluangkan waktu di luar sekolah untuk mengerjakan pekerjaan sekolah dan untuk memenuhi kebutuhan saya, saya 
mencari pekerjaan sampingan dan jika di Tanya dengan ketepatan waktu gajian sejauh ini sudah cukup tepat waktu kecuali awal tahun biasannya terdapat keterlambatan dikarenakan biasanya APBD belum ketuk palu biasanya seperti itu" (IW).

Berdasarkan dari hasil wawancara yang didapatkan diatas dimana dapat dilihat bahwasannya masih kurangnya gaji yang diberikan dengan keadaan dimana saat ini kebutuhan hidup semakin meningkat dimana lagi dengan beban tugas yang tidak berat membuat para guru merasa kurang cukup dalam hal gaji terutama bagi para honorer.

Sama seperti hasil yang penulis wawancarai pada informan sebagai berikut: "jika di Tanya tentang harapan gaji tentunya ingin naik dikarnakan kebutuhan semakin banyak dan jika di Tanya tentang gaji sudah sesuai dengan pekerjaan menurut saya masih kurang sesuai dikarnakan pekerjaan yang saya kerjakan di bilang banyak namun di Tanya tentang ketepatan waktu gajian di terima tepat waktu" (RON).

Berdasarkan hasil wawancara para guru dapat disimpulkan bahwasannya setiap guru ingin sekali naik gaji dengan kebutuhan semakin lama semakin meningkat sehingga membuat para guru merasa kekurangan dalam hal kebutuhan dan diiringi beban kerja yang banyak menambah buruknya terhadap penerimaan gaji yang menurut para guru tidak sesuai sehingga jika gaji yang diterima tidak cokok dengan beban kerjanya membuat para guru kurang termotivasi dan kurang terdorong untuk mengajar di sekolah tersebut. Dapat dilihat juga dari hasil observasi dimana di jumpai guru yang bekerja di luar dari pekerjaannya di sekolah untuk memenuhi kebutuhannya.

\section{Penyajian Data}

1. Motivasi Kerja Intrinsik

Hasil Penyajian Data

\begin{tabular}{|c|c|c|}
\hline No & Indikator & Penyajian Data \\
\hline 1 & Keberhasilan & $\begin{array}{l}\text { 1. Salah satu } \\
\text { operator terbaik } \\
\text { yang diberikan } \\
\text { oleh dinas } \\
\text { pendidikan } \\
\text { sebagai operator } \\
\text { administrasi dan } \\
\text { pengolahan di } \\
\text { sekolah } \\
2 . \\
\text { Membimbing } \\
\text { murid dalam } \\
\text { perlombaan } \\
\text { OSN jenis Sains } \\
\text { memperoleh } \\
\text { peringkat ketiga } \\
\text { 3. } \\
\text { Memperoleh } \\
\text { penghargaan } \\
\text { satyalencana } \\
\text { karya sastra x } \\
\text { tahun } 2017 \\
\text { tingkat nasional }\end{array}$ \\
\hline 2 & $\begin{array}{c}\text { Pengakuan/peng } \\
\text { hargaan }\end{array}$ & $\begin{array}{l}\text { 1. Ucapan } \\
\text { terimakasih atas } \\
\text { pengabdian }\end{array}$ \\
\hline
\end{tabular}




\begin{tabular}{|c|c|c|}
\hline & & $\begin{array}{l}\text { sebagai guru } \\
\text { 2. Ucapan } \\
\text { terimakasih,piag } \\
\text { am dan } \\
\text { cindramata }\end{array}$ \\
\hline 3 & $\begin{array}{c}\text { Pekerjaan itu } \\
\text { sendiri }\end{array}$ & $\begin{array}{l}\text { 1. Memahami } \\
\text { dan mengerti } \\
\text { tentang } \\
\text { pekerjaan yang } \\
\text { di emban } \\
\text { 2. Merangkap } \\
\text { pekerjaan } \\
\text { 3. Pekerjaan } \\
\text { diberikan tidak } \\
\text { sesuai dengan } \\
\text { pendidikan dan } \\
\text { keahlian }\end{array}$ \\
\hline 4 & Tanggung jawab & $\begin{array}{l}\text { 1. Mengajar } \\
\text { sesuai ketentuan } \\
\text { dan jadwal, } \\
\text { serta menyusun } \\
\text { RPP dalam } \\
\text { kegiaatan } \\
\text { pembelajaran. } \\
\text { 2. Tidak tepat } \\
\text { waktu dalam } \\
\text { mengajar karena } \\
\text { ada guru yang } \\
\text { merangkap } 2 \\
\text { mata pelajaran } \\
\text { dalam sehari } \\
\text { mengajar }\end{array}$ \\
\hline 5 & Pengembangan & $\begin{array}{l}\text { 1. Beberapa } \\
\text { guru telah } \\
\text { mendapatkan } \\
\text { sertifikat } \\
\text { pendidik } \\
\text { 2. Guru telah } \\
\text { mengikuti } \\
\text { program } \\
\text { pelatihan. } \\
\text { 3. Pihak } \\
\text { sekolah sangat } \\
\text { mengapresiasi } \\
\text { untuk guru yang } \\
\text { akan } \\
\text { melanjutkan } \\
\text { pendidikan ke } \\
\text { jenjang yang } \\
\text { lebih tinggi. }\end{array}$ \\
\hline
\end{tabular}

Sumber: Data penelitan yang diolah (2021)
Dalam hal ini triangulasi data membandingkan jawaban informan kunci dan informan pendukung, sebagai berikut:

Triangulasi Data Motivasi Kerja Intrinsik

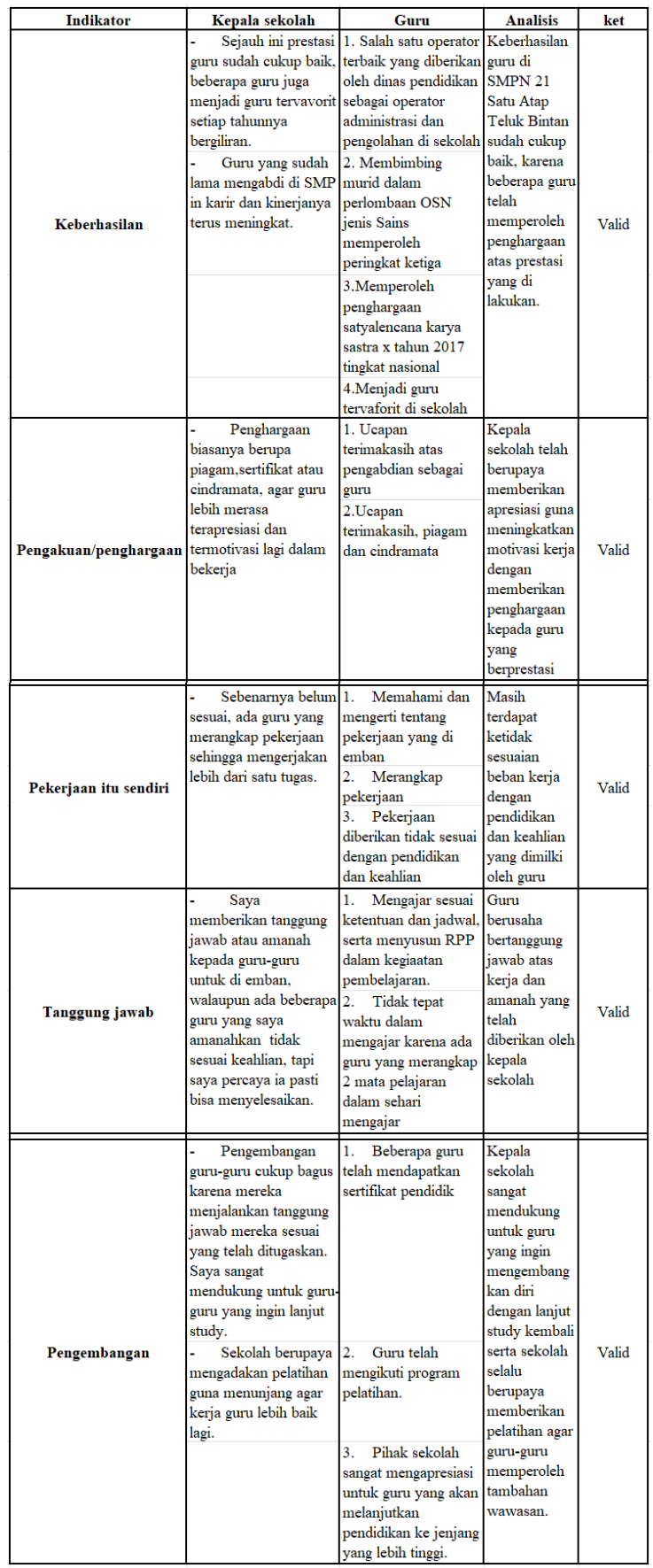

Sumber: Data penelitan yang diolah (2021)

Triangulasi Data Motivasi Ekstrinsik

\section{Triangulasi}




\begin{tabular}{|c|c|c|c|c|}
\hline Indikator & \begin{tabular}{|l|} 
Kepala sekolah \\
\end{tabular} & Guru & Analisis & Ket \\
\hline $\begin{array}{c}\text { Kebijakan dan } \\
\text { administrasi }\end{array}$ & $\begin{array}{l}\text { - Saya rasa } \\
\text { sudah cukup } \\
\text { jelas, saya } \\
\text { sampaikan } \\
\text { dengan Bahasa } \\
\text { baik }\end{array}$ & \begin{tabular}{|l|l} 
1. Arahan & \\
dari atasan & \\
cukup & 1 \\
dipahami & \\
oleh & 1 \\
sebagian & turu \\
2. Terdapat \\
guru yang \\
sulit \\
memahami \\
arahan yang \\
diberikan
\end{tabular} & \begin{tabular}{|l|} 
Sebagian besar \\
guru-guru \\
memahami \\
arahan yang \\
kepala sekolah \\
berikan
\end{tabular} & Valid \\
\hline $\begin{array}{c}\text { Hubungan antar } \\
\text { pribadi }\end{array}$ & 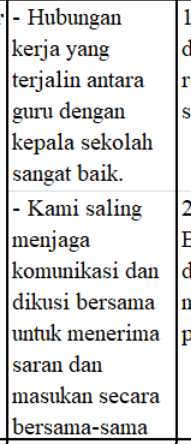 & \begin{tabular}{|l|l} 
1. Hubungan & dengan \\
rekan kerja \\
sangat baik
\end{tabular} & \begin{tabular}{|l|} 
Hubungan \\
kerja yang \\
terjalin antara \\
guru dengan \\
kepala sekolah \\
sangat baik. \\
Dan kepala \\
sekolah serta \\
guru saling \\
berkomunikasi \\
dan diskusi.
\end{tabular} & Valid \\
\hline Kondisi kerja & \begin{tabular}{|l|l} 
- Kondisi kerja & 1 \\
ini sudah cukup & $\mathrm{F}$ \\
baik, sekolah & $\mathrm{p}$ \\
berupaya dan & $\mathrm{n}$ \\
berusaha & $\mathrm{b}$ \\
memberikan & $\mathrm{s}$ \\
fasilitas dan alat & $\mathrm{n}$ \\
bantu kerja yang & \\
bisa menunjang & 2 \\
motivasi kerja & $\mathrm{k}$ \\
guru, walaupun & $\mathrm{c}$ \\
belum semua & \\
terlengapi. &
\end{tabular} & \begin{tabular}{l|l}
1. & \\
Fasilitas dan & k \\
perlengkapa & y \\
n disekolah & $\mathrm{b}$ \\
belum & $\mathrm{f}$ \\
sepenuhnya & $\mathrm{s}$ \\
memadai & $\mathrm{n}$ \\
& \\
2. Kondisi \\
kerja sudah \\
cukup baik
\end{tabular} & \begin{tabular}{|l|} 
Terdapat \\
kondisi kerja \\
yang cukup \\
baik, namun \\
fasilitas belum \\
sepenuhnya \\
memadai
\end{tabular} & Valid \\
\hline Gaji & \begin{tabular}{|l} 
- Saya rasa untuk \\
saat ini sudah \\
sesuai gaji yang \\
diberikan dengan \\
jenjang yang guru- \\
guru miliki, yaa.. \\
walaupun saya tahu \\
mungkin ada \\
beberapa guru yang \\
merasa gajinya \\
belum cukup untuk \\
memenuhi \\
kebutuhan sehari- \\
hari. Saya berusaha \\
memberikan hak \\
guru tepat waktu, \\
namun untuk guru \\
honorer kadang \\
terjadi \\
keterlambatan tapi \\
saya berusaha \\
sebisa mungkin \\
untuk memberikan \\
hak guru tepat \\
waktu.
\end{tabular} & 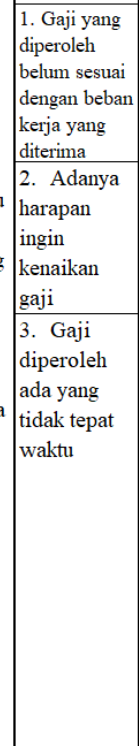 & $\begin{array}{c}\text { Gaji diperoleh } \\
\text { sebagian tidak } \\
\text { tepat waktu }\end{array}$ & Valid \\
\hline
\end{tabular}

Sumber: Data penelitan yang diolah (2021)

\section{Penarikan Kesimpulan}

Berdasarkan hasil wawancara dengan responden untuk variabel motivasi kerja untuk faktor intrinsik yang terdiri dari keberhasilan adalah baik, penghargaan adalah baik, untuk pekerjaan itu sendiri adalah kurang baik, tanggung jawab adalah kurang baik, dan pengembangan adalah baik. Kemudian untuk faktor ekstrinsik yang terdiri dari kebijakan dan administrasi adalah baik, hubungan antar pribadi adalah baik, untuk kondisi kerja adalah kurang baik dan gaji adalah kurang baik.

Dalam penarikan kesimpulan hasil wawancara antar informan kunci dan informan pendukung terdapat beberapa penyataan yang sesuai/valid. Seluruh data terkait indikator di dapatkan melalui wawancara dan juga observasi, penarikan kesimpulan ini dilihat dari observasi serta tanya jawab yang peneliti lakukan dengan beberapa informan pendukung dan informan kunci. Oleh karena itu berdasarkan penarikan kesimpulan pada tiap-tiap variebel dan indikator, maka peneliti menyimpulkan bahwa analisis motivasi kerja guru di SMP Negeri 21 Satu Atap Teluk Bintan Kabupaten Bintan adalah baik.

\section{PENUTUP}

\section{Simpulan}

Berdasarkan hasil uraian bab IV, dapat ditarik kesimpulan sebagai berikut:

1. Untuk variabel motivasi intrinsik indikator keberhasilan SMP N 21 Satu Atap tingkat keberhasilan guru dengan hasil jawaban responden adalah baik. Dikarenakan sudah terdapat beberapa guru yang mengalami karir yang 
meningkat dan sudah mendapatkan pencapaian yang diraih salah satunya guru terfaforit dan lain-lain.

2. Untuk variabel motivasi intrinsik indikator penghargaan SMP N 21 Satu Atap dimana hasil yang di peroleh dari hasil jawaban responden adalah baik. Dikarenakan kepala sekolah telah memberikan penghargaan kepada guru yang berhasil dan berkompeten dalam pembelajaran.

3. Untuk variabel motivasi intrinsik indikator pekerjaan itu sendiri SMP N 21 Satu Atap dimana dengan tugas dalam pekerjaanan yang di lakukan oleh guruguru dengan hasil jawaban responden adalah kurang baik. Dikarenakan terdapat guru merasa bosan dalam pekerjaannya dan terdapat beberapa guru yang belum sesuai dngan pekerjaannya.

4. Untuk variabel motivasi intrinsik indikator tanggung jawab SMP N 21 Satu Atap dengan tanggung jawab yang diberikan oleh atasan dengan hasil jawaban responden kurang baik. Dikarnakan atasan memberikan tanggung jawab belum sesuai dengan yang dimiliki oleh beberapa guru.

5. Untuk variabel motivasi intrinsik indikator pengembangan SMP N 21 Satu Atap sudah berkembang guru-guru yang berada di SMP tersebut dengan hasil jawaban responden adalah baik. Dikarenakan pihak sekolah selalu berusaha untuk membuat guru berkembang dalam pengetahuannya dengan cara meberikan pelatihanpelatihan dan menganjurkn untuk guru menimbah ilmu di perguruan tinggi agar menambah pengetahuannya.

6. Untuk variabel motivasi ektrinsik indikator kebijakan dan administrasi SMP N 21 Satu Atap sudah menerapkan kebijakan dengan baik dan dengan hasil jawaban dari responden adalah baik. Dikarenakan pengarahan yang di berikan oleh kepala sekolah sudah cukup jelas dan mudah dimengerti.

7. Untuk variabel motivasi ektrinsik indikator hubungan antar pribadi SMP N 21 Satu Atap sudahkah hubungan antar pekerja dan atasan baik dengan hasil jawaban responden adalah baik. Dikarenakan hubungan kepala sekolah dan guru sudah baik dan saling berkordinasi dan mencari solusi bersama dalam memecahkan permasalahan yang ada di sekolah.

8. Untuk variabel motivasi ektrinsik indikator kondisi kerja SMP N 21 Satu Atap sudahkah kondisi kerja dan fasilitas yang beradi di SMP sudah baik dengan hasil jawaban responden adalah kurang baik. Dikarenakan kondisi kerja sudah cukup nyaman namun fasilitas yang ada di sokolah tersebut masih ada yang belum memadai.

9. Untuk variabel motivasi ektrinsik indikator gaji SMP N 21 Satu Atap sudah mendapatkan gaji sesuai dengan 
pekerjaan yang dilakukan dan tepat waktu dari hasil jawaban responden adalah kurang baik. Dikarenakan terdapat beberapa guru yang merasa gaji yang diperoleh belum sesuai dengan pekerjaan yang di jalaninya.

\section{Saran}

Adapun saran-saran yang dapat diberikan dalam penelitian ini adalah sebagai berikut:

1. Sebaiknya atasan melakukan analisis beban kerja setra memberikan target kerja sehingga guru merasa tenang dan tidak jenuh atau bosan, membuka dan memberikan jaminan jenjang karier bagi guru sehingga mereka merasa masa depannya terjamin selama bekerja di sekolah ini, serta memberikan peluang yang sama bagi semua guru atau pegawai untuk maju dan berprestasi.

2. Kondisi kerja yang meliputi jam kerja, keamanan kerja, fasilitas serta system administrasi dan kebijakan sekolah juga harus terus di perhatikan dan ditinjau ulang sehingga benar-benar memberikan perasaan nyaman dan kemudahan bagi guru dalam bekerja.

3. Dalam meningkatkan motivasi kerja guru maka kepala sekolah dapat senantiasa memberikan motivasi kepada guru dengan memberikan kenyamanan dalam bekerja, memberikan penghargaan insentif yan lebih baik lagi bagi guru yang berprestasi memberikan pelatihan kerja, memberikan pengakuan terhadap hasil kerja guru dengan memberikan kenaikan gaji, bonus, ataupun reward.

4. Kepala sekolah perlu memberikan kesempatan kepada guru untuk mengikuti program sertifikasi guru bagi guru yang belum memiliki sertifikasi pendidikan agar kesejahteraan dan kualitas guru meningkat.

\section{DAFTAR PUSTAKA}

Horne, James C Van dkk. 2009. Prinsipprinsip Manajemen Keuangan. Edisi keduabelas buku 1. Jakarta: Salemba Empat.

Hartatik, I. P. (2014). Buku Praktis Mengembangkan SDM. jogjakarta: Laksana.

Hasibuan, M. (1014). Manajemen Sumberdaya Manusia (Edisi Revi). Jakarta: Bumi Aksara.

Marni, Sri Endang Mastuti, M. U. (2013). Analisis Motivasi Kerja Guru Ekonomi SLTA Swasta Di Kecamatan Pemangkat Kabupaten Sambas. 1-11.

Sedarmayanti. (2016). Manajemen Sumber Daya Manusia: Reformasi Birokrasi Dan Manajemen Pegawai Negeri Sipil. Refika Aditama.

Tim STIE Pembangunan Tanjungpinang. 2014. Panduan Penulisan Skripsi dan Panduan Penulisan Jurnal. Tanjungpinang: STIE Pembangunan Tanjungpinang.

Tim Unesa. 2000. Pedoman Penulisan Artikel Jurnal. Surabaya: Unesa Press.

Winardi, J. (2011). Motivasi Pemotivasian Dalam Manajemen. Jakarta: PT RAJAGRAFINDO PERSADA. 